International Journal of Public Health Excellence (IJPHE)

Vol. 1, No. 1, January 2022, 41 45

Journal homepage: https://ejournal.ipinternasional.com/index.php/ijphe/

ISSN: 2809-9826, DOI: https://doi.org/10.55299/ijphe.v1i1.8

\title{
The Effect of Soybean and Meloon Juice on Increasing Breast Milk Production in Mothers
}

\author{
Darma Afni Hasibuan', Sri Sartika Sari Dewi' ${ }^{2}$, Yunita Bella Donna ${ }^{3}$ \\ ${ }^{1}$ Matorkis Academy of Midwifery, Padangsidimpuan, Indonesia \\ ${ }^{2}$ Aufa Royhan University, Padangsidimpuan, Indonesia \\ ${ }^{3}$ Public Health Center Employee, North Padangsidimpuan District, Padangsidimpuan, Indonesia
}

\begin{abstract}
Article Info
Article history:

Received November 22, 2021

Revised December 12, 2021

Accepted January 05, 2022

\section{Corresponding Author:}

Darma Afni Hasibuan

Matorkis Academy of

Midwifery, Padangsidimpuan,

Indonesia

Email:

afnihasibuan87@gmail.com

ABSTRACT

Soybean (Glycine Max) juice has many nutritional benefit beside full nutrient, its potension can be used to stimulate hormone of oxytocin and prolactin that are benefit for increasing production of mother's milk. The information about an exclusive mother's milk is just $45.95 \%$ babies get the intake and it is lower from the target in which the national data in the year 2018 show $68.74 \%$ babies have well mother's milk intake. This research is taken to know the effect of giving soybean and melon juices toward the improvement mother's milk production on the breastfeeding mothers. The research method is quocy experimental with sample about 20 people. Technique for sampling is purposive sampling. The result shows that there is an effect of giving soybean and melon juices with $p$ - value $=.000$ with improvement of mother's milk production. The conclusion, there is an effect for improving mother's milk production by giving soybean and melon juices. Therefore, it is expected for the breastfeeding mothers should apply this knowledge in order it is one optional way to improve the production of mother's milk on the breastfeeding mothers.
\end{abstract}

\section{Keywords:}

Soybean and Melon Juices, Mother's Milk Production, Breastfeeding Mothers

This article is licensed under a Creative Commons AttributionShareAlike 4.0 International License.

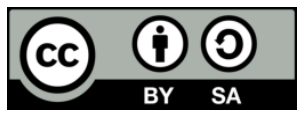

\section{INTRODUCTION}

Worldwide only about $40.0 \%$. Indonesia in 2020 , which is $37.3 \%$, still has not reached the target set by the government according to the 2015 - 2019 Strategic Plan data for exclusive breastfeeding coverage of 50\% in 2019 [16]. In Indonesia, several studies have been developed on plants or fruit that can help breast milk production which is associated with breast milk production, prolactin hormone levels including the provision of soy bean and melon juice to increase breast milk production at Tigaraksa Health Center [8].

Based on data from the health profile of North Sumatra Province in 2018, the percentage of exclusive breastfeeding was $59.10 \%$. North Sumatra Province is ranked 5th from the bottom of all provinces in Indonesia. However, when compared to the national exclusive breastfeeding coverage target in 2018, it is $8.74 \%$. North Sumatra Province is considered still unable to achieve the 2018 North Sumatra Health target). Meanwhile, Medan City has a prevalence of exclusive breastfeeding at $34.5 \%$ [18].

Based on the profile of the Padangsidimpuan City Health Office in 2018, exclusive breastfeeding was 45.95\%. Based on the profile of the Padangsidimpuan City Health Center WekI, 7.7\%. The research researched by Winarni et al, (2020) entitled the effect of giving soybean and melon juice on increasing breast milk production at the Tiga Raksa Public Health Center in Tangerang Regency. With the results obtained a p-value of 0.00 which means that there is a difference in breast milk production before and after being given soy bean and melon juice. Soybean and melon juice can be used as an alternative to increase breast milk production. 


\section{METHOD}

This research is a quantitative type with a quasi-experimental design whose design uses the one group pretest - post-test. This design consists of one group that has been determined by treatment. This research was conducted at the Wek I Public Health Center, Padangsidimpuan City in 2021. From December 2020-June 2021. The population in this study was 32 people. The sampling technique used was purposive sampling. Bivariate analysis was conducted to determine the difference between the two variables in this study. Bivariate test was conducted to determine the effect of soybean juice and melon on increasing milk production in breastfeeding mothers. The test used was a paired one-group T-test. Giving is said to have an effect if the p-value $<0.05$.

\section{RESULTS AND DISCUSSION}

\subsection{Results}

Table 1. Description of Respondents Characteristics.

\begin{tabular}{lcc}
\hline \multicolumn{1}{c}{ Age } & Frequency & Percent $\%$ \\
\hline$<20$ Year & 1 & 5 \\
\hline$>35$ Year & - & - \\
\hline $20-35$ Year & 19 & 95 \\
\hline Total & $\mathbf{2 0}$ & $\mathbf{1 0 0}$ \\
\hline \multicolumn{1}{r}{ Work } & Frequency & Percent $\%$ \\
\hline Housewife & 10 & 50 \\
\hline Be at work & 10 & 50 \\
\hline Total & $\mathbf{2 0}$ & $\mathbf{1 0 0}$ \\
\hline
\end{tabular}

Based on table 1 shows the frequency distribution of the majority age 20-35 years as many as 19 people (95\%). While the work of IRT respondents was 10 people (50\%), and 10 people worked (50\%).

Table 2. Breast Milk Production Before Giving Soybean And Melon Juice

\begin{tabular}{cccccc}
\hline Respondent & \multicolumn{5}{c}{ Milk Production $(\mathbf{m l})$} \\
\hline Mean & Median & SD & Min & Max \\
\hline Pre Test & $\mathbf{2 2 5}$ & $\mathbf{2 2 0}$ & $\mathbf{2 2 , 1}$ & $\mathbf{2 0 0}$ & $\mathbf{2 7 0}$ \\
\hline
\end{tabular}

Based on table 2, the average value before giving soy bean and melon juice is the mean $225 \mathrm{ml}$, the lowest value is $200 \mathrm{ml}$, the highest value is $270 \mathrm{ml}$.

Table 3. Breast Milk Production After Giving Soybean And Melon Juice

\begin{tabular}{cccccc}
\hline Respondent & \multicolumn{5}{c}{ Milk Production $(\mathbf{m l})$} \\
\hline Mos Test & $\mathbf{3 0 4}$ & Median & SD & Min & Max \\
\hline
\end{tabular}

Based on table 3 shows the average value after administration of soya bean and melon juice is mean $304 \mathrm{ml}$, median $305 \mathrm{ml}$, lowest value $210 \mathrm{ml}$, highest value $350 \mathrm{ml}$.

Table 4. Breast Milk Production Distribution

\begin{tabular}{lcc}
\hline \multicolumn{1}{c}{ Breast milk production } & Frequency & Percent $\%$ \\
\hline Not increasing & 1 & 5 \\
\hline increase & 19 & 95 \\
\hline Total & $\mathbf{2 0}$ & $\mathbf{1 0 0}$ \\
\hline
\end{tabular}

Based on table 4 shows the majority experienced increased milk production as many as 19 people (95\%).

Table 5. Paired T Test Results after Giving Soybean And Melon Juice At the Health Center Wek I.

\begin{tabular}{cccccc}
\hline Variable & $\mathrm{N}$ & Mean & SD & Correlation & Sig \\
\hline Breast milk production & $\mathbf{2 0}$ & $\mathbf{3 0 2}$ & $\mathbf{3 2 , 7}$ & $\mathbf{4 , 2 6}$ & $\mathbf{0 , 0 0}$ \\
\hline
\end{tabular}

Based on table 5, the results of the paired group t-test obtained a p-value of 0.00 , which means that there is a difference between breast milk production and after being given soy bean and melon juice. The results of statistical tests showed that there was a significant difference between before and after being given soybean and melon juice on increasing breast milk production in breastfeeding mothers in the Wek I Public Health Center, Padangsidimpuan City, the $\mathrm{p}$ value $=0.00(\mathrm{p}<0.05)$. This shows that Ha is accepted, which means that there is an effect of giving after the intervention. 


\subsection{Discussion}

\subsubsection{Characteristics of Respondents based on age}

Based on research on the characteristics of respondents based on the age of 20-35 years as many as 19 people (95\%) of 20 people. Age has a big influence on the development of mother's knowledge and behavior, because the higher the mother's age, the easier it is to receive the information that has been conveyed [26].

Conceptually, the age group of 20-35 years is based on the effective age in producing breast milk [26]. These results are supported by research by [10]. Where the majority of the mother's age is 20-35 years as many as 19 people (95\%). In this study, respondents aged $<20$ years were still too young. For their thoughts were still immature and it was difficult to give information about how to increase breast milk production in breastfeeding mothers, while those aged $>35$ years had difficulty starting to lose their selfconfidence so that it was difficult to give information about how to increase breast milk production in breastfeeding mothers. breastfeeding mothers.

\subsubsection{Description of Respondents Characteristics by Job}

Based on the results of the study, it is known that the respondents as IRT are as many as 10 people $(50 \%)$. As a housewife, mothers rarely interact with sources of information that can provide information on how to increase breast milk production, this causes respondents in the breastfeeding process not to do anything that can support milk production, for example by increasing the quality of consumption and doing breast care that can support breastfeeding. milk production process.

Work is not an excuse not to give breast milk, because breast milk can be expressed and still given to babies even though they cannot accompany their babies, breastfeeding can be done before going to work, if they are at home, mothers are obliged to give their children the right to breastfeed with their own milk [1]. Mothers still lack knowledge of nutritional status or nutritional content that can facilitate breast milk production and there is still a lack of knowledge of working mothers about storing breast milk and lack of knowledge of working mothers about the benefits of breastfeeding [3].

By breastfeeding the baby directly, the mother has implemented the Natural Contraceptive Method (MAL), which is a simple method of contraception that is effective without any contraception until the mother has not had her period [25]. In this study, breastfeeding mothers who only served as IRT often experienced a lack of milk production because the activities they carried out were too many so that their nutritional intake was lacking, so that it had an impact on breast milk production.

\subsubsection{Increase in breast milk production after being given Soybean and Melon Juice}

The results showed that melon. almost all (95\%) experienced an increase in breast milk production after giving soy bean juice. Soybean starch has a lot of nutritional content and benefits. Its potential in stimulating the hormones oxytocin and prolactin such as alkaloids, polyphenols, steroids, flavonoids and other substances is effective in increasing and facilitating milk production during breastfeeding [29]. Research by Muhartono et al., 2018 on papaya contains laktagogum which is a substance that can help increase and facilitate the release of breast milk. Lactagogums have the effect of stimulating the release of the hormones oxytocin and prolactin such as alkaloids, polyphenols, steroids, flavonoids which are effective in increasing the secretion and expenditure of breast milk.

This study is in line with research conducted [17]. The increase in breast milk production after the intervention was obtained by an average increase of $56.75 \mathrm{ml}$, although there were 2 people who experienced a decrease in breast milk production. In this study, giving soy bean and melon juice to nursing mothers produced energy for nursing mothers,

so that breastfeeding mothers do not experience a lack of energy and have an impact on the lack of milk production. By increasing milk production after giving soy bean and melon juice, breastfeeding mothers can avoid anxiety about carrying out their duties as mothers, namely giving breast milk to their babies. Mother's anxiety sometimes leads to depression or stress that leads to the baby blues. Giving soy bean and melon juice to breastfeeding mothers can increase the baby's immunity because it contains vitamins E, B1, B2, B3, and protein. In this study, there were respondents who experienced no increase in breast milk production after the post test because the nutritional value and benefits contained in soybean and melon juice were used by the body for the recovery process.

\subsubsection{The Effect of Giving Soybean and Melon Juice to Increase Breast Milk Production}

The results of the statistical test $\mathrm{T}$ - paired test showed that the value of $\mathrm{p}$ - value $=0.00$ with a limit of significance of $\mathrm{p}$ - value was $<0.05$ meaning Ha was accepted and Ho was rejected, it can be concluded that there is an effect of giving soy bean juice and melon to increase breast milk production. after being given for 5 days, there were 19 people (95\%) whose milk production increased and 1 person (5\%) whose milk production did not increase. 
The results of this study are in accordance with the results of research by Winarni et al., 2020, which shows that the paired $\mathrm{T}$ test is $\mathrm{p}$ - value $=0.00$ with a limit of meaning $\mathrm{p}$ - value is 0.05 , then $\mathrm{Ha}$ is accepted and ho is rejected, it can be concluded that there is an effect of giving peanut juice soybeans and melons on increasing breast milk production after being given for 7 days, namely 19 people (95\%) breast milk production increased and 1 person (5\%) breast milk production did not increase.

The results of this study are in accordance with the results of research by Elika Puspitasari, 2015 which shows the $\mathrm{p}$-value $=0.00(\mathrm{p}<0.05)$ it can be concluded that there is an effect of giving soy bean juice and melon to increase breast milk production in postpartum mothers and 5 people $(12,5 \%)$ breast milk is smooth. From the results of the research above, it can be concluded that soy and melon juice can increase milk production in breastfeeding mothers. Because in the essence of soybeans and melons contain nutrients and benefits, their potential can stimulate the hormone oxytocin and prolactin such as alkaloids, polyphenols, steroids, flavonoids and other substances effective in increasing and facilitate the production of breast milk (Puspita Sari, 2018).

\section{CONCLUSION}

There is an effect of giving soy bean and melon juice to increase breast milk production in breastfeeding mothers at Wek I Public Health Center, Padangsidimpuan City. It is hoped that the respondents after this research is carried out will increase their knowledge about how to increase breast milk production. By carrying out this research, the results of this study can be used as additional knowledge and skills for health workers in providing health education to breastfeeding mothers on how to increase breast milk production.

\section{ACKNOWLEDGEMENTS}

Author thanks Sri Sartika, Sari Dewi and Yunita Bella Donna. In most cases, sponsor and financial support

\section{REFERENCES}

[1] Astutik, Postpartum and Breastfeeding Midwifery Care, Vol. 1, $1^{\text {st }}$ ed, CV Transinfo Media, Jakarta, 2015

[2] Bobak, Normal Postpartum Midwifery Care Textbook, Vol. 1, $1^{\text {st }}$ ed, Buku Kedokteran EGC, Jakarta, 2016

[3] Padangsidimpuan Health Office, "Padangsidimpuan City Exclusive Breastfeeding Coverage", [2018] Padangsidimpuan

[4] Dr Taufan, Postpartum Parenting Textbook. Vol. 1, $1^{\text {st }}$ ed, Nuha Medika, Yogyakarta, 2014

[5] GERMAS, "World Breastfeeding Week, Breastfeeding: Mothers Protected, Children Strong, Earth Healthy August 5, 2020". [2020] dinkessurakarta.go.id /Pekan-ASI-sedunia-Menyusui-ibu-terlindungi-anak-kuat-Bumi-kuatsehat/TargetCakupanASIEksklusifsxsrf=Alekk030nifTZjjdh3rualcYm3BKOqTq:1627405136706\&q=Target+cakupan + ASI+Eksklusif $+2018+$ secara $+\&$ spellnasional=1\&ved=2ahUKEwj

[6] Hidayat, A A, Research Methods and Data Analysis Techniques. Vol. 2, $2^{\text {nd }}$ ed, Salemba Medika, Jakarta, Indonesia, 2017

[7] Kulstum, Medical and Islamic Birth \& Breastfeeding Consultation, Vol. 3, $3^{\text {rd }}$ ed, Toobagus, Bandung, Indonesia, 2018

[8] Kristiyana,W, Breastfeeding Breastfeeding and Realizing, Vol. 1, $1^{\text {st }}$ ed, Nuha Medika, Jogjakarta, Indonesia, 2011

[9] Luthfa nurridha, "Busui needs to consume these 7 types of fruit to launch breast milk production" [2018]. October 20, 2020: https//www.popmama.com>pregnancy >Birth.Mb manager (2020)5manfatkacangkedelaiuntukmeningkatkanproduksiASIperah.19oktober 2020.https://dekatibucoid>

[10] Lusiana Mustinda, "Food", [2020] detik.com/info-kuliner/d-4893594/ini-cara-membuat-susu-kedelai-yang-enak-dirumah. October 20, 2020

[11] Vonia Lucky, Pradhtiya Rizqi, "Fresh Fruits that are Good for Breastfeeding Mothers”, [2019] July 19, 2019, https:/www.motherAnd baby.co.id>artikel>.

[12] Muhartono, The Effect of Giving Papaya Fruit (Carica papaya) on the smooth production of breast milk (ASI) in breastfeeding mothers, Vol. $1,1^{\text {st }}$ ed, Explore, Jakarta, 2018.

[13] Notoatmodjo, Health Research Method. Vol. 2, $2^{\text {nd }}$ ed, Rineka Cipta, Jakarta, 2016

[14] Notoatmodjo, Health Research Method. Vol. 1, $2^{\text {nd }}$ ed, Rineka Cipta, Jakarta, 2010.

[15] Nursalam, Concept and Application of Nursing Research Methodology, Vol. 1, $1^{\text {st }}$ ed, Salemba Medika, Jakarta, 2017.

[16] Ministry of Health data and information center, "Indonesian Health Profile”. [2018], Jakarta

[17] Pratiwi, "Analysis of Factors Associated with Exclusive Breastfeeding for Adolescent Mothers in Kemayoran Village, Krembang District”, B.S. Thesis, AKBID S, Surakarta, 2015.

[18] North Sumatra Provincial Health Office, "North Sumatra Health Profile", [2018]. North Sumatra Provincial.

[19] Puspita sari,E, "Jurnal Kebidanan", "The Effect of Soy Milk Provision on Increases in Postpartum Mothers in Rb Bina Sehat Bantul", Vol. 2, No. 2 pp 60-68, June, 2018, doi :10.26714/jk.7.1.2018.54-60

[20] Pratiwi, G. E. Maryanto, S. And Pontang ,G. S. "Tahun'Jurnal Gizi dan Kesehatan”, “The Effect of Giving Smoothies Mixed Ambon Banana and Melon on Blood Pressure in Women with Hypertension Age 45-59, Vol. 2, No. 3, pp 47-53, June, 2018, doi:1035473/jgkv10i23.47.

[21] R. Y. Astutik S.M, Breast and Lactation, Vol 1, $1^{\text {st }}$ ed, Salemba Medika, Jakarta, Indonesia, 2014.

[22] Ministry of Health, "Renstra Exclusive Breastfeeding Coverage". [2015-2019] Ministry of Health, Jakarta.

[23] Sugiono, Research procedure, Vol. 3, $3^{\text {rd }}$ ed, Rineka Cipta, Jakarta, Indonesia, 2013.

[24] SDK, Management, Vol. 1, $1^{\text {st }}$ ed, Laktasi, Jakarta, Indonesia, 2016.

[25] Sulistiyawati Ari, Midwifery Care in Postpartum, Vol. 2, $2^{\text {nd }}$ ed, Andi Offset, Yogyakarta, Indonesia, 2017

[26] Sari, "Jurnal Keperawatan”, "Overview of the Factors Affecting Exclusive Breastfeeding in Kunciran Village”, B.S. Thesis, Vol. 2, No. 2, pp. 44-49, June, 2017, Tangerang, 2017.

[27] Sulistiyawati,Ari, Textbook of Midwifery Care for Postpartum Mothers, Vol. 1, $1^{\text {st }}$ ed, Andi Offset, Yogyakarta, Indonesia, 2015.

[28] Suraatmadja, Early breastfeeding is constrained due to milk production and milk ejection, Vol. 1, $1^{\text {st }}$ ed, Andi Press, Palu, Indonesia, 2018 Int Jou of PHE 
[29] Siti Amina dan Wikanastri Hersoelistyorini, "Chemical Characteristics of Cereal Sprouts Flour and Peanuts with Blanching", [2015] LPPM UNIMUS Research Results Seminar.

[30] Winarni, Wibisono, Veronica, Giving Soybean and Melon Juice to Increase Breast Milk Production and Baby Weight at Tigaraksa Health Center.Vol. 3, No.1, pp. 34, September, 2020 